\title{
Bruk av studentresponssystem i nettundervisning
}

\author{
Kjetil Liestøl Nielsen, Universitetet i Sørøst-Norge
}

\begin{abstract}
SAMMENDRAG: I denne artikkelen vil jeg presentere ulike måter studentresponssystem (SRS) kan brukes for å håndtere noen av utfordringene med nettbasert undervisning, slik som kommunikasjon mellom lærer og student, og hvordan legge opp til, og følge opp, gruppearbeid og faglige samtaler på en god måte. Artikkelen vil vise praktiske tips med å gjennomføre Peer Instruction-metoden, en populær SRS-metode for å fremme faglige samtaler og kritisk tenking, samt vise hvordan man kan bruke systemet til å fange opp usikkerheter hos studenter i gruppearbeid og oppgaveløsning, og hvordan dette kan brukes til å bedre tilpasse gjennomganger av oppgaver.
\end{abstract}

\section{INTRODUKSJON}

Nettundervisning ble den dominerende undervisningsformen ved høyere utdanning i Norge da universiteter og høgskoler ble stengt som følge av COVID-19. Denne undervisningsformen har derimot flere utfordringer som skiller seg fra klasseromsundervisning. Studenter vegrer seg ofte mot å komme inn i det digitale undervisningsrommet med webkameraet skrudd på [1] og det kan også være vanskelig å få alle studentene til å svare på spørsmål og gi tilbakemeldinger gjennom en åpen chat hvor samtlige kan se hva man skriver. Dette kan gjøre det vanskelig å få til effektiv kommunikasjon mellom lærer og studenter. I tillegg kan den fysiske adskillelsen mellom lærer og student føre til en $\varnothing \mathrm{kt}$ transaksjonsavstand hvor misforståelser lettere oppstår [2]. Moore argumenterer for at en stor transaksjonsavstand også kan bidra til en følelse av isolasjon blant studenter som igjen kan føre til lavere motivasjon og engasjement [2], noe vi også har sett i mediebildet etter at universiteter og høgskoler ble stengt.

I denne artikkelen vil jeg se på hvordan studentresponssystem (SRS) kan brukes som et verktøy for å håndtere noen av utfordringene med nettundervisning. Et studentresponssystem er en fellesbetegnelse for programvare hvor man som lærer kan stille spørsmål til studenter, ofte i form av en quiz med forhåndsdefinerte svaralternativer, og hvor studentene svarer på disse spørsmålene via nettleseren på en PC/Mac, nettbrett eller smarttelefon. Svarene fra studentene blir dermed oppsummert og visualisert hos lærerens del av programvaren. I tillegg til å knytte bruken av SRS opp mot et teoretisk perspektiv og forskning på SRS, og argumentere for hvordan denne bruken har potensiale for å gi økt motivasjon hos studentene, vil jeg også gi praktiske tips til programvaren som brukes.

\section{FREMME FAGLIGE SAMTALER}

I høyere utdanning blir studentresponssystemer ofte brukt som et verktøy for å fremme faglige samtaler og kritisk tenking hos studentene i en forelesning gjennom å presentere studentene konseptuelle quizzer som de skal diskutere sammen i grupper (se f.eks. [3]). I tillegg kan bruk av SRS fungere som et nyttig avbrekk for å skape variasjon i undervisning slik at man holder på konsentrasjonen til studentene. Dette kan være spesielt viktig i nettundervisning siden det kan være langt flere distraksjoner når man sitter alene hjemme foran en PC enn når man sitter sammen med medstudenter i et klasserom. En populær måte å organisere bruken av SRS for å fremme faglige samtaler, er ved å legge inn en individuell tenkepause og avstemming før studentene begynner å diskutere, den såkalte Peer Instruction-metoden [3]. Å inkludere en slik individuell tenkepause og avstemming kan bidra til mer argumentasjon i gruppediskusjonene og bedre gruppedynamikk [4]. I en studie forklarte studentene dette med at den individuelle tenkepausen gjør at man lettere kan bidra i diskusjonen og at man i mindre grad blir påvirket av sterke parter i gruppen ved at man har fått tid til å danne sin egen mening før den blir "farget" av de andre i gruppen [5]. Dette kan argumenteres å gi en $\varnothing \mathrm{kt}$ følelse av autonomi, som blir beskrevet av selvbestemmelsesteori (SDT) som et av tre universelle psykologiske behov som påvirker et individs motivasjon og adferd [6]. Ved å ha tenkt over oppgaven før diskusjonen, forklarte studentene at de følte de ville ha ber å bidra med i gruppediskusjonene siden de hadde fått tenkt over spørsmålet på forhånd [5]. De får brukt sin kompetanse på en bedre måte enn om de går rett inn i diskusjonen, noe som muligens kan føre til økt motivasjon da "behov for kompetanse" er et av de tre sentrale behovene SDT beskriver. 
Det siste behovet beskrevet av STD, behov for tilhørighet, altså at man føler at man er en del av et fellesskap, vil jeg komme tilbake til senere i denne artikkelen.

Når man skal organisere gruppediskusjoner i en nettundervisnings $ø \mathrm{kt}$, har man noen fordeler sammenliknet med campus-undervisning. I konferanseprogrammet "Zoom", f.eks., kan man lett lage studentgrupper med bruk av "Breakout rooms", hvor man kan velge om studentene skal tilfeldig plasseres automatisk i de ulike gruppene, eller om man gjør dette manuelt. Som underviser kan man enkelt starte gruppediskusjonene og sende studentene inn i egne gruppediskusjonsrom. Like enkelt kan man også avslutte diskusjonene og kalle studentene tilbake til hovedrommet. Det kan også være enklere å organisere den individuelle tenkepausen og avstemming i en nettundervisnings $ø$ kt. I campusundervisning må man oppfordre studentene til å ikke snakke sammen før etter den individuelle avstemmingen, og satse på at studentene følger denne oppfordringen. På nett kan man derimot få studentene til å tenke og stemme individuelt før man sender studentene inn i gruppediskusjonene med breakout rooms.

Peer Instruction-metoden setter noen krav til programvaren som brukes. Det er få studentresponssystem på markedet som legger direkte opp til bruk av PI-metoden, men man kan likevel legge opp til metoden ved å legge inn to identiske spørsmål etter hver hverandre; en for hver av avstemmingene. Det er en fordel om man bruker et system hvor man har mulighet til å vente med å se resultatene av avstemmingene til etter man er ferdig med den andre avstemmingen. Å se resultatet fra den første avstemmingen kan ødelegge den kommende gruppediskusjonen, spesielt hvis det er et alternativ som er i tydelig flertall [6].

\section{UTTRYKKE SIKKERHET}

Svarene fra en SRS-økt kan gi læreren en pekepinn på om studentene henger med i forelesningen, noe lærer kan bruke til å tilpasse undervisningen underveis i en forelesning. Det er derimot viktig å ikke legge for mye vekt på svarene fra en SRS- $\varnothing$ kt. Det er mange aspekter som kan påvirke hvordan studentene svarer som de gjør, slik som å bli påvirket av sterke parter i en gruppe [5,7] eller at de svarer riktig uten å helt ha forstått hvorfor dette er riktig [5]. Dette kan potensielt gi læreren et feil inntrykk av kunnskapsnivået til en klasse, noe studentene også selv er klare over. Dette kan føre til at studenter unngår å svare dersom de er usikre i frykt for å villede foreleseren ved at de tilfeldigvis gjetter riktig [8]. En mulighet for å unngå denne problematikken, kunne vært å inkludere et "Vet ikke"-alternativ, noe studenter selv har etterlyst [8].

Selv har jeg derimot aldri "vet ikke" som et alternativ i min SRS-bruk da jeg ønsker at alt fokus er på oppgaven og de gitte alternativene. Min hypotese er at man tenker dypere på en oppgave dersom man tvinges til å ta et standpunkt. Det er også flere graderinger av å være usikker. Man kan være usikker på et svar, men likevel peke seg inn mot et bestemt alternativ i en quiz. Burde man da velge dette alternativet, eller burde man gå for "vet ikke" for å ikke risikere å gi inntrykk at man har forstått mer enn man har? Det er likevel en viktig problemstilling siden man mister fordelene SRS kan bidra med dersom studentene ikke svarer. Dette er kanskje enda viktigere for nettundervisning hvor man ikke har den samme muligheten til å gå rundt blant gruppene for å veilede og få et inntrykk av hvorvidt studentene har forstått temaet. En måte å håndtere denne utfordringen kan være å stille oppfølgingsspørsmål til SRS-oppgavene. Etter at studentene har svart på et quiz-spørsmål, starter man en ny avstemming hvor de stemmer på hvor sikre de var på sitt svar. Ulempen med dette er at det vil øke tiden som går til SRSquizzen. Hvis man lager quizzene ferdig på forhånd i programvaren man bruker, er man også avhengig å alltid huske å legge til et vurderingsspørsmål etter hvert spørsmål i quizzen. En annen mulighet er å inkludere et ekstra sett med alternativer til hvert quiz-spørsmål som indikerer hvor sikre studentene er på svaret sitt. Studentene får da beskjed at de både skal velge hvilket alternativ de tror er riktig i tillegg til å markere hvor sikre de er. På denne måten får studentene uttrykke sin usikkerhet, i tillegg til at de må ta et standpunkt hvilket svar de tror er riktig eller i det minste heller mot. Dette forutsetter at SRSprogrammet man bruker tillater at studenter velger flere alternativer på quizzene. Figur 1 viser et eksempel på dette med bruk av studentresponssystemet Socrative [9].

En utfordring med begge disse fremgangsmåtene, er at man ikke får noen kobling mellom hva studentene har svart og hvor sikre de er, kun hvor mange som er sikre/usikre. Dette har man derimot mulighet til i studentresponssystemet Mentimeter [10] ved å bruke "segmentation of answers". Denne gjør at man kan sammenlikne studentenes svar over flere spørsmål. Ved å først ha quiz-spørsmålet og deretter et oppfølgingsspørsmål om hvor sikre de var, kan man få vist hva studentene svarte på quizzen 
i ulike farger på svarfordelingen på oppfølgingsspørsmålet hvor sikre de var. Dette er viktig informasjon for å kunne tilpasse undervisningen på best mulig måte i etterkant av en quiz (hvis studenter har svart riktig alternativ, er det nyttig å vite om de var sikre på dette svaret eller om de bare gjetter). Ulempen med bruk av "segmentation of answers" i Mentimeter, er at vi er tilbake til å kjøre dobbelt så mange avstemminger for hver quiz, en for selve svaret og en for hvor sikre de var, i tillegg til at man alltid må huske å legge til et vurderingsspørsmål etter hvert quiz-spørsmål når man lager quizzene.

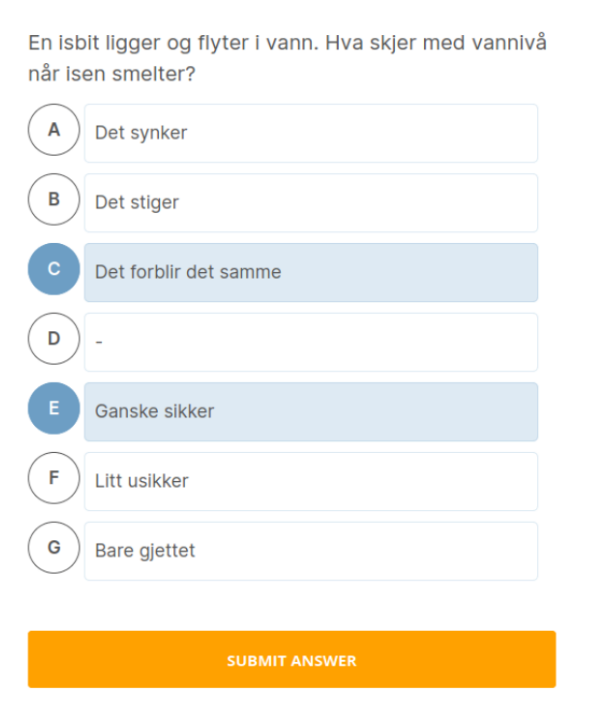
1. En isbit ligger og flyter i vann. Hva skjer med vannivå når isen smelter?

\section{Hide Results 10/10 Students Answered}

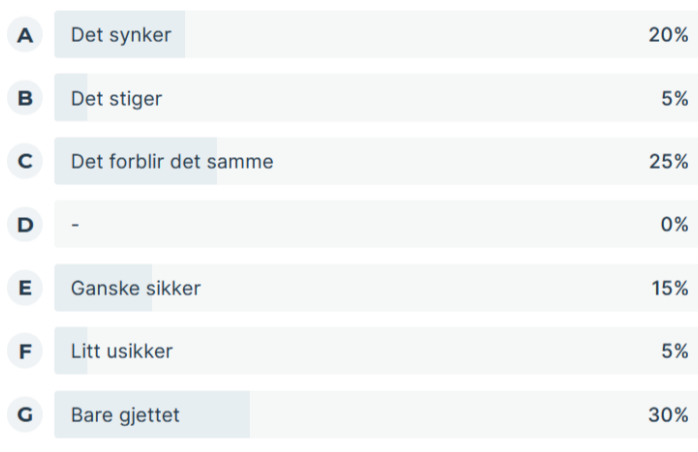

Fig. 1. Bruk av Socrative hvor studentene (venstre) har et ekstra sett med alternativ hvor de stemmer på hvor sikre de er på sitt svar. Alternativ D er et "dummy"- alternativ for å visuelt skille mellom svaralternativene på selve quizen og usikkerhetsalternativene.

I 2020 startet jeg på utviklingen av et nytt studentresponssystem, KLN Response, hvor denne utfordringen er håndtert ved at uttrykking av usikkerhet er bygd inn i programvaren og noe læreren kan aktivere på hver quiz. Foreløpig fungerer dette ved at studentene kan trykke flere ganger på alternativene de skal velge for å endre hvor sikre de er på sitt svar. Usikkerheten blir så visualisert ved ulike former for skraveringer på stolpediagrammet som viser resultatet av avstemmingen. Figur 2 viser et eksempel på dette. Legg merke til at svarfordelingene er den samme som i figur 1, men her har læreren vesentlig mer informasjon pga. koblingen mellom hva studentene har svart og hvor sikre de er. KLN Response er ment som et fremtidig gratis alternativ (åpen kildekode) til kommersielle systemer på markedet (se [11] for mer informasjon).
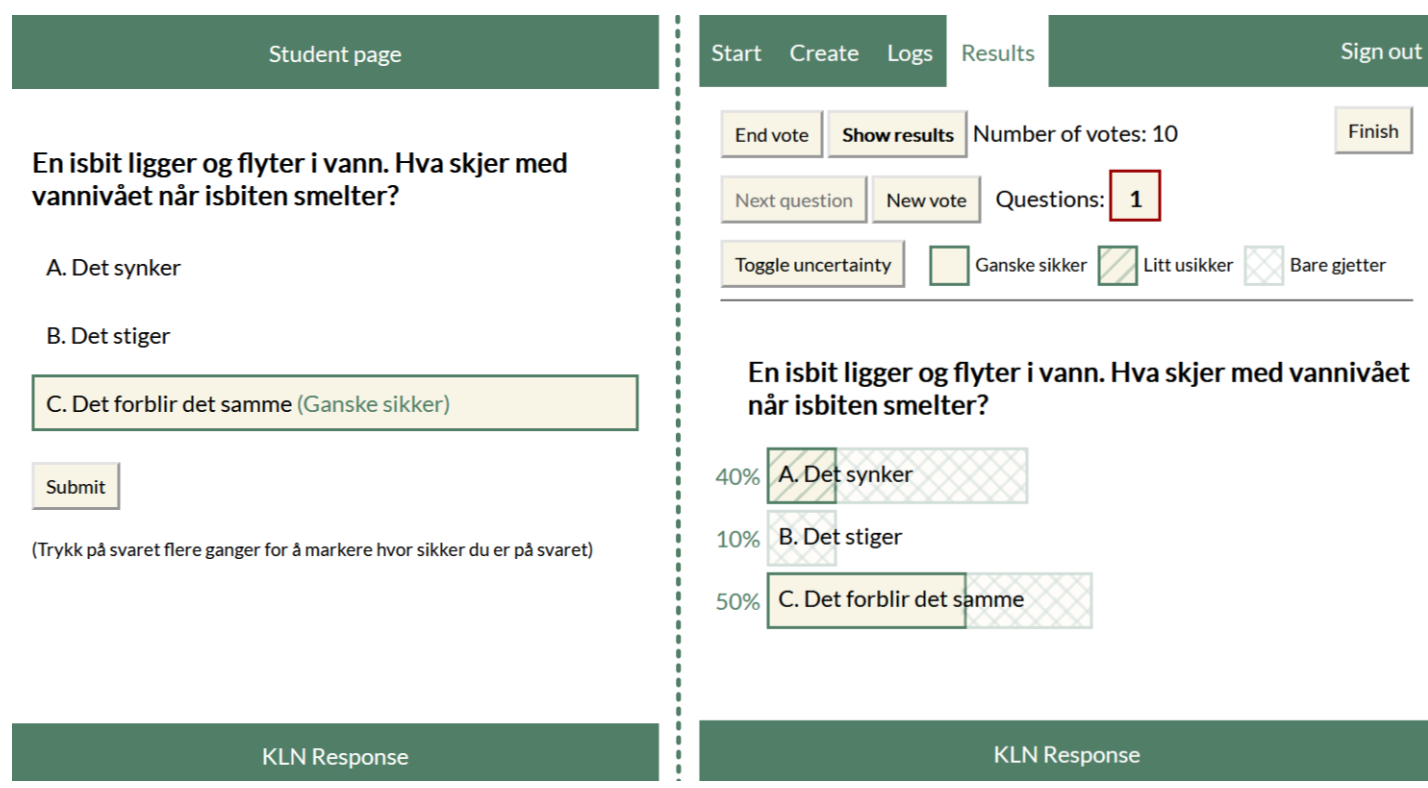

En isbit ligger og flyter i vann. Hva skjer med vannivået når isbiten smelter?

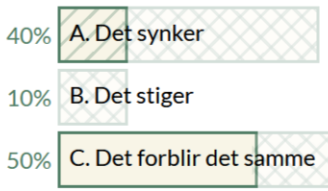

KLN Response

Fig. 2. Bruk av KLN Response med "evaluate uncertainty"-funksjonaliteten. Studentene (venstre) kan markere hvor sikre de er på svaret sitt ved å trykke flere ganger på svaralternativet. Dette visualiseres hos lærer (høyre) ved ulik skravering på stolpediagrammet. 


\section{OPPFØLGING AV OPPGAVELØSING}

Veiledning av gruppearbeid kan være en større utfordring i nettundervisning. I Zoom er det enkelt å dele studentene inn i grupper og starte gruppearbeid, men det er begrensede kommunikasjonsmuligheter underveis i gruppearbeidet. Man kan logge seg inn i studentenes grupperom, men dette tar tid og er ikke alltid gunstig for korte gruppeoppgaver. SRS kan da fungerer som et kommunikasjonsverktøy hvor man får et inntrykk av studentenes forståelse, samt en tilbakemelding fra studentene på hvorvidt de følte de forstod oppgaven. Det er derimot ikke alle oppgaver som passer som en SRS-quiz med forhåndsdefinerte svaralternativer, men SRS kan likevel være et godt verktøy for kommunikasjon mellom lærer og student. Figur 3 viser en generell quiz med tre spørsmål som kan være nyttig for oppfølging av gruppearbeid i nettundervisning. Det første spørsmålet, "Hvordan gikk det på oppgaven", kan kjøres idet studentene kommer tilbake fra gruppearbeidet, eller allerede idet studentene begynner på gruppearbeidet. Man kan da si at de skal svare på spørsmålet når de har gjort oppgavene, slik at man som lærer får et inntrykk av når studentene begynner å bli ferdige slik at man kan vurdere om man skal avslutte gruppearbeidet tidlig, eller gi studentene mer tid. Dersom alle studentene svarer at de forstod oppgaven uten problemer, trenger man sannsynligvis ikke bruke lang tid på gjennomgangen av oppgaven. Er det mange som svarer at de ikke fikk til oppgaven, er det et tegn på at gjennomgangen trenger mer tid.
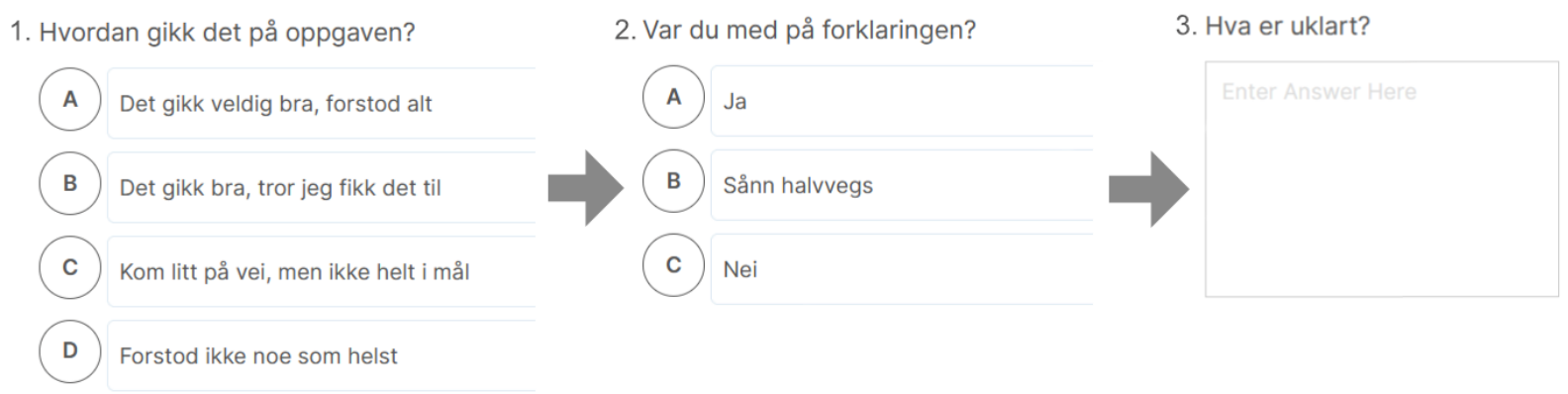

Fig. 3. Quiz med tre spørsmål som kjøres ved oppgaveregning, her ved bruk av Socrative.

Etter at man har gitt en forklaring, starter man spørsmål 2, "Var du med på forklaringen". Dersom alle var med, går man videre i forelesningen. Var det derimot mange som ikke var helt med på forklaringen, er det et tegn på at man burde forklare oppgaven enda en gang. For at den andre gjennomgangen skal være mest mulig effektiv, startes spørsmål 3, "Hva var uklart", hvor studentene skriver fritt hva de følte var uklart med oppgaven eller forklaringen (dette forutsetter at programvaren åpner for at studentene kan svare med fritekst, noe som er mulig i både Socrative og Mentimeter). Istedenfor å gjennomgå oppgaven i sin helhet andre gang, kan man spare tid ved å fokusere forklaringen inn mot hva studentene skrev som svar på spørsmål 3. I videolenken under viser jeg et eksempel på disse tre stegene tatt fra en hybridundervisningsøkt (studenter både på nett og i klasserommet) i matematikk på lærerutdanningen ved USN. Spørsmålene er ikke formulert helt likt som i figur 3, men prinsippet bak spørsmålene er det samme (videoen er redigert ned for å spare tid). Her kan vi se hvordan SRS ble et viktig verktøy for å avdekke at studentene ikke hadde forstått en oppgave, og hvordan det videre ble brukt for å avdekke "hvor skoen trykker".

\section{https://web01.usn.no/ knielsen/misc/pedagogisk mappe/vid/klikkere tilbakemelding.mp4}

Dette er selvsagt spørsmål man også kunne stilt i chatten i nettforelesningsprogrammet man bruker, men bruk av SRS har her en fordel ved at man svare anonymt, noe som kan føre til økt deltagelse i tillegg til at man får kjapt oppsummert svarene fra studentene. Samtidig viser man studentene at de blir ivaretatt og at man bryr seg om deres læring og utfordringer med fagstoffet. Her legger man opp $\varnothing \mathrm{kt}$ motivasjon gjennom fokus på tilhørighetsbehovet i henhold til selvbestemmelsesteori ved at man skaper en større nærhet mellom lærer og student. Tilhørighetsbehovet er også et ekstra argument for å legge opp til faglige samtaler og gruppearbeid i nettundervisning. I tillegg til at gruppearbeid følger et sosialkonstruktivistisk læringsperspektiv, kan det også være nødvendig for å gi studentene den nødvendige følelsen av å være en del av en klasse, spesielt dersom de følger nettundervisningen foran PC-en alene fra hjemmet.

Denne bruken av SRS legger også opp til å gi studentene en økt følelse av autonomi da de ser at de har mulighet til å påvirke undervisningen gjennom sine svar, f.eks. ved at de påvirker hva lærer fokuserer på i gjennomgangene av oppgavene. I tillegg legger man opp til et økt fokus på metakognisjon og 
selvregulert læring. Studentene må ikke bare tenke over hvorvidt de følte de fikk til oppgaven, men også hva som var uklart, hva de føler de har forstått og hva de føler de ikke har forstått. En slik selvevaluering er en viktig del av selvregulert læring [12]. Dette kan muligens føre til at studentene går dypere inn i oppgaven enn hva de ville gjort uten denne bruken av SRS, noe som potensielt kan føre til økt læring.

\section{KONKLUSJONER OG VEIEN VIDERE}

I denne artikkelen har jeg vist måter studentresponssystem (SRS) kan brukes i nettundervisning for å håndtere noen av utfordringene med denne undervisningsformen, slik som kommunikasjon mellom lærer og student og som et verktøy for å fremme faglige samtaler. Jeg viste også hvordan SRS kan brukes som et verktøy for lettere oppfølging av oppgaver studenter jobber med i forelesningene, samt hvordan man kan legge opp SRS-spørsmål til å fange opp hvor sikre studentene er på at de har forstått oppgavene og hva de syns er vanskelig. Metodene som har blitt presentert i denne artikkelen stiller visse krav til programvaren som brukes. Både Socrative og Mentimeter er her gode alternativer. I artikkelen har jeg argumentert for at metodene som er nevnt har potensiale for å gi en økt motivasjon hos studentene, samt også muligens økt læringseffekt, siden metodene legger opp til å dekke de mentale behovene som beskrives av selvbestemmelsesteori. Dette er derimot noe som må undersøkes nærmere i fremtidige forskningsstudier.

\section{REFERANSER}

[1] Damsgaard, H. L. (2020). Svarte skjermer i digitale undervisningsrom. Khrono. https://khrono.no/gode-grunner-til-svarte-skjermer/483367

[2] Moore, M. G. (2013). The Th eory of Transactional Distance. In Handbook of distance education (pp. 84-103). Routledge.

[3] Crouch, C. H., \& Mazur, E. (2001). Peer instruction: Ten years of experience and results. American journal of physics, 69(9), 970-977. https://doi.org/10.1119/1.1374249

[4] Nielsen, K. L., Hansen, G., \& Stav, J. B. (2016). How the initial thinking period affects student argumentation during peer instruction: students' experiences versus observations. Studies in Higher Education, 41(1), 124-138. https://doi.org/10.1080/03075079.2014.915300

[5] Nielsen, K. L., Hansen-Nygård, G., \& Stav, J. B. (2012). Investigating peer instruction: How the initial voting session affects students' experiences of group discussion. ISRN education, 2012. https://doi.org/10.5402/2012/290157

[6] Deci, E. L., \& Ryan, R. M. (2008). Facilitating optimal motivation and psychological well-being across life's domains. Canadian psychology/Psychologie canadienne, 49(1), 14. https://psycnet.apa.org/doi/10.1037/0708-5591.49.1.14

[7] Nicol, D. and Boyle, J. (2003). Discussion in large classes: a comparison of two interaction methods in the wired classroom. Studies in Higher Education, 28, 457-473. https://doi.org/10.1080/0307507032000122297

[8] Nielsen, K. L., Hansen, G., \& Stav, J. B. (2013). Teaching with student response systems (SRS): teacher-centric aspects that can negatively affect students' experience of using SRS. Research in Learning Technology, 21. https://doi.org/10.3402/rlt.v21i0.18989

[9] Socrative (u.å.). https://www.socrative.com/

[10] Mentimeter (u.å.). https://www.mentimeter.com/

[11] Nielsen, K. L. (u.å.). https://web01.usn.no/ knielsen/kln response/app/

[12] Zimmerman, B. J. (2002). Becoming a self-regulated learner: An overview. Theory into practice, 41(2), 64-70. https://doi.org/10.1207/s15430421tip4102_2 